\title{
On the Financial Risk Evaluation of Chinese Banking Industry in the Perspective of Organizational Immune Theory
}

\author{
Xiao-Qiang Ma, Hui-Yun Zhao \\ School of Economics and Management, Northwest University, Xi'an, China \\ E-mail: xiaoqiang_ma@nwu.edu.cn, coralinezhao@163.com
}

\begin{abstract}
With the deepening of Chinese reform, the financial risk has become a big problem of banking industry. To choose effective means to identify and measure such risk of Chinese banking industry is of great significance. As an emerging field of management, organizational immune theory applies the theory of immune mechanism of living organisms in biology into the enterprise ecosystem, which can help to explore the risk management and the stability of the enterprise. In this paper, we use the organizational immune theory and catastrophe progression method (CPM) to evaluate and study the financial risk immune ability of the selected 16 listed banks from 2010 to 2015 and put forward the revelations of financial risk management according to the evaluation results. It helps the banking industry to identify their financial risks, eliminate some threats and form memory activities to maintain the healthy development.
\end{abstract}

Keywords-financial risk management; organizationzal immune theory; Chinese bankingindustry; model indicators

\section{INTRODUCTION}

Since 2013, the financial risk of Chinese banking industry has increased significantly. The accurate identification and objective evaluation of such risks, especially the use of more advanced theoretical guidance to do so is very important. Yihua Wang, a professor of TsingHua university, (2005) first proposed the application of biological immune theory and mechanism into explaining the problems in enterprise management. He also puts the concept, mechanism and characteristics of organizational immunity in the field of management. Lv Ping (2006) used organization immunity from the dimensions of the organizational cognitive, organizational defense, and organizational memory to explain the organizational adaptation. Chunlan Dai (2013) discussed the connotation of immunization and studied the relationship between it and the internal control and designed an evaluation index system of enterprise internal control. Nan Wang (2015) established a structural equation model in view of the organizational immunity. In China, there is little research to study enterprise financial risk management based on immunization theory.

In the of research of financial risk management, William Beaver (1966) 's single variable of the financial early warning model and Edward Altman 's (1968) Z score model laid a foundation for financial crisis warning. Such research in China starts relatively late. Shouhua Zhou et.al. (1996) put up F score model on the basis of early research abroad, which make up the deficiency of the $\mathrm{Z}$ score model not fully considering the lack of cash flow changes. In recent years, construction of financial risk early warning model has been further refined. Shu Yang (2005) build a BP neural network model based on cross section data of a sample of 120 listed companies. Weian Li, et. al., (2007) built an early-warning index system based on the six dimensions of NanKai index (CCGINK) and the enterprise early warning model according to conditional probability method.

\section{THE THEORETICAL ANALYSIS OF FINANCIAL RISK EARLY WARNING AND ORGANIZATIONAL IMMUNITY}

Financial risk management is mainly based on the accounting information of an enterprise to set up the early warning indicators through calculation, statistics, analysis and monitoring methods. Thus, early warning, real-time monitoring and control in advance of financial risk of the enterprise can be done with the observation of the changes of financial indicators. The financial risk management system has the following three basic functions information collection, risk prediction, and risk control.

Organizational immune theory is a kind of new thought by using the mechanism of biological immune theory to explain the problems of enterprise management. This theory argues that there exists a kind of ability in the process of survival, development and operation of the enterprise, which makes it pay close attention to changes in the environment to eliminate and resist the occasional change of the external environment by creating an ecosystem for itself. This kind of capacity is the organizational immune capacity.

The enterprise risk management system has the characteristics of immunology. There is a high degree of fusion of enterprise risk management theory and the organizational immune theory. In a changing environment, the environment observation has a positive effect on the promotion of enterprise performance. Taking effective risk management measures ensures good performance of the enterprise. Enterprises could obtain a new competitive advantage in the competition environment after learning and sum up the experience of risk management. This process of risk management is similar to the immune system's response to threats: the process of cognition, defense, and memory. 


\section{EVALUATION INDICATORS SET OF THE BANKING INDUSTRY'S FINANCIAL RISK IN THE PERSPECTIVE OF ORGANIZATION IMMUNE THEORY}

\section{A. Financial Risk Analysis of Listed Banks}

With the opening-up and economic growth, Chinese banks has developed rapidly. They pay great attention to expand their market share and earn more profits. Meanwhile they also face more and more financial risks. Research on financial risk management in China was proposed later than the developed countries. The obsolete of risk management idea and the lack of risk management innovation inhibit the development of the banking industry. Especially after China's economy entered the New Normal, financial risk become more severe.

\section{B. Financial Risk Immune Indicators}

TABLE I. FINANCIAL RISK IMMUNE MODEL OF LISTED BANKS

\begin{tabular}{|c|c|c|}
\hline $\begin{array}{c}\text { Destination } \\
\text { Layer A }\end{array}$ & Primary Index B & Secondary Index C \\
\hline \multirow{8}{*}{$\begin{array}{l}\text { Financial } \\
\text { risk immune } \\
\text { ability of } \\
\text { listed bank }\end{array}$} & \multirow[b]{2}{*}{$\begin{array}{l}\text { Debt-paying immune } \\
\text { ability B1 }\end{array}$} & Asset-liability ratio $\mathrm{C} 1$ \\
\hline & & $\begin{array}{c}\text { Non-performing assets ratio } \\
\mathrm{C} 2\end{array}$ \\
\hline & \multirow{3}{*}{$\begin{array}{l}\text { Operating immune } \\
\text { ability B2 }\end{array}$} & Current ratio $\mathrm{C} 3$ \\
\hline & & Loan-to-deposit ratios C4 \\
\hline & & Capital adequacy ratio C5 \\
\hline & \multirow{3}{*}{$\begin{array}{l}\text { Earning immune } \\
\text { ability B3 }\end{array}$} & Earnings per share C6 \\
\hline & & Return on equity $\mathrm{C} 7$ \\
\hline & & Cost-income Ratio C8 \\
\hline
\end{tabular}

\section{The Establishment Basis of Financial Risk Immune Model Indicators}

\section{1) Identification.}

When a key factor appear which may harm the enterprise financial status, the immune system of financial risk can give warning in advance in order to remind the business operators to prepare early or take measures to reduce the financial loss. Debt-paying immune indicators can be measured by quick ratio, liquidity ratio and asset-liability ratio. Whether the enterprise is able to repay debts in time or not is an important sign of enterprise financial situation. The enterprise's sustainability and risk can be examined through the analysis of debt paying ability, and future earnings could also be predicted in this way.

\section{2) Defense.}

The narrow operating ability of an enterprise refers to the enterprise's assets operation efficiency, which embodied crisis response ability of the enterprise management. In financial management of an enterprise, operating ability means the enterprise's ability to use the assets to make a profit. The financial analysis ratios of an enterprise's operation ability include the liquidity ratio, non-performing assets ratio, capital adequacy ratio, etc. Not only financial risk can be predicted and forecast, but also the cause of enterprise financial conditions deteriorate can be found in time with effective financial risk immune system when symptoms of crisis appear. In this way, enterprise managers could know the deep reason of the financial crisis and formulate effective measures to prevent financial conditions deterioration to avoid serious financial crisis.

\section{3) Memory.}

On the one hand, effective financial risk early warning system can help the enterprise avoid the existing financial crisis in time; on the other hand, the enterprise also finds causes and solutions of the crisis and puts forward suggestions timely in order to make up the defects of the existing enterprise financial management and improve the immune system of financial risk, which provides similar warning example in the future and eliminate hidden dangers fundamentally. Earning ability refers to the enterprise profit ability, usually characterized by business income amount and level within a certain period of time. In reality, the listed enterprise often uses earnings per share, return on equity index to evaluate the earning ability. The enterprise's risk response ability and learning ability and can be seen through the analysis and summary of profit immune ability. Moreover, the enterprise can reduce the risk and improve the profit ability constantly through the anticipation and early warning of financial crisis.

Above all, the primary index reflects three different dimensions of the financial risk respectively. Through the recognition of the danger, in view of the risk factors and determine the degree of risk in the face of the experience of learning, we set up a "recognition - defense -- memory" system which provides a new cognition and interpretation for bank's financial risk immune ability.

\section{THE EVALUATION MODEL AND FINANCIAL RISK IMMUNE ABILITY EVALUATION OF CHINESE BANKING INDUSTRY}

This study uses Catastrophe Progression Method (CPM) to evaluate and analyze the financial risk immune ability of selected 16 listed banks and put forward their risk management strategy according to the results of the evaluation. According to the research purposes, the destination layer index was processed by multi-level and ranking decomposition, and then arranged as a tree target hierarchy. The destination layer index was decomposed into sub indexes which include debt-paying immune ability, operating immune ability and earning immune ability. Only the lowest level evaluation index data should be collected in this method. The selected evaluation index values of this paper period are from 2010 to 2015. Because of the difference of each index in this evaluation system which contained the content, dimensions and dimensional units, primary data was dimensionless processed according to the requirements of catastrophe progression method. For example, in 2015. 
TABLE II. FINANCIAL RISK IMMUNE MODEL OF LISTED BANKS IN 2015 IN CHINA

\begin{tabular}{|c|c|c|c|c|c|c|c|c|}
\hline NAME & XC1 & XC2 & XC3 & XC4 & XC5 & XC6 & XC7 & XC8 \\
\hline SPDB & 0.80 & 0.47 & 0.52 & 0.90 & 0.32 & 1.00 & 1.00 & 0.02 \\
\hline HXB & 1.00 & 0.44 & 0.60 & 0.87 & 0.00 & 0.59 & 0.92 & 1.00 \\
\hline CMBC & 0.56 & 0.49 & 0.68 & 0.86 & 0.14 & 0.37 & 0.87 & 0.72 \\
\hline CMB & 0.67 & 0.54 & 1.00 & 1.00 & 0.38 & 0.83 & 0.89 & 0.45 \\
\hline NJCB & 0.71 & 0.00 & 0.84 & 0.00 & 0.50 & 0.79 & 0.77 & 0.19 \\
\hline CIB & 0.94 & 0.40 & 0.86 & 0.61 & 0.07 & 0.98 & 0.99 & 0.00 \\
\hline BOB & 0.79 & 0.19 & 0.00 & 0.89 & 0.31 & 0.38 & 0.60 & 0.25 \\
\hline ABC & 0.58 & 1.00 & 0.68 & 0.55 & 0.56 & 0.02 & 0.66 & 0.87 \\
\hline BOCOM & 0.26 & 0.44 & 0.69 & 0.83 & 0.58 & 0.18 & 0.00 & 0.65 \\
\hline ICBC & 0.00 & 0.43 & 0.54 & 0.74 & 0.96 & 0.12 & 0.79 & 0.29 \\
\hline CEB & 0.46 & 0.50 & 0.84 & 0.86 & 0.22 & 0.06 & 0.33 & 0.40 \\
\hline CCB & 0.10 & 0.48 & 0.67 & 0.92 & 1.00 & 0.19 & 0.88 & 0.40 \\
\hline BOC & 0.01 & 0.38 & 0.74 & 0.96 & 0.71 & 0.03 & 0.17 & 0.50 \\
\hline ECITIC & 0.83 & 0.38 & 0.65 & 0.88 & 0.22 & 0.17 & 0.24 & 0.47 \\
\hline PAB & 0.74 & 0.40 & 0.79 & 0.66 & 0.02 & 0.49 & 0.40 & 0.72 \\
\hline NBCB & 0.29 & 0.44 & 0.64 & 0.81 & 0.57 & 0.00 & 0.23 & 0.52 \\
\hline
\end{tabular}

According to the basic principle and model of CPM, we use the formula of CPM normalized three-level indicators and gradually composite the score of three secondary indexes including debt-paying immune ability, operating immune ability and earning immune ability. After that, repeat the previous steps until the listed bank financial risk immune ability score is concluded as table 3 and 4 . The most popular three types of CPM are sharp point mutation, dovetail mutation system and butterfly mutation system. Sharp point mutation model is:

$f(x)=x[4]+a x[2]+b x$;

Butterfly mutation model is :

$f(x)=\{(1 / 5) x[5]\}+\{(1 / 3)$ ax [3] $\}+\{(1 / 2)$ bx [2] $\}+c x$;

The normalization formula was derived with the bifurcation equation of CPM:

$x[, a]=a[1 / 2], x[, b]=b[1 / 3]$,

$\mathrm{x}[$, a $]$ means $\mathrm{x}$ corresponds to value $\mathrm{a} ; \mathrm{x}[, \mathrm{b}]$ means $\mathrm{x}$ corresponds to value $b$

TABLE III. FINANCIAL RISK IMMUNE ABILITY EVALUATION RESULT OF LISTED BANKS IN 2015 (1)

\begin{tabular}{|l|l|l|l|l|l|l|l|l|}
\hline NAME & C1 & C2 & C3 & C4 & C5 & C6 & C7 & C8 \\
\hline SPDB & 0.78 & 0.78 & 0.97 & 0.80 & 0.56 & 1.00 & 1.00 & 0.38 \\
\hline HXB & 1.00 & 0.76 & 0.97 & 0.84 & 0.00 & 0.77 & 0.97 & 1.00 \\
\hline CMBC & 0.75 & 0.79 & 0.96 & 0.88 & 0.38 & 0.61 & 0.96 & 0.92 \\
\hline CMB & 0.82 & 0.82 & 1.00 & 1.00 & 0.62 & 0.91 & 0.96 & 0.82 \\
\hline NJCB & 0.84 & 0.00 & 0.00 & 0.95 & 0.71 & 0.89 & 0.92 & 0.66 \\
\hline CIB & 0.97 & 0.74 & 0.88 & 0.95 & 0.27 & 0.99 & 1.00 & 0.00 \\
\hline BOB & 0.89 & 0.57 & 0.97 & 0.00 & 0.56 & 0.62 & 0.84 & 0.71 \\
\hline ABC & 0.76 & 1.00 & 0.86 & 0.88 & 0.75 & 0.14 & 0.87 & 0.97 \\
\hline BOCOM & 0.51 & 0.76 & 0.95 & 0.88 & 0.76 & 0.43 & 0.00 & 0.90 \\
\hline ICBC & 0.00 & 0.75 & 0.93 & 0.81 & 0.98 & 0.35 & 0.93 & 0.73 \\
\hline CEB & 0.68 & 0.79 & 0.96 & 0.94 & 0.47 & 0.24 & 0.69 & 0.79 \\
\hline CCB & 0.32 & 0.78 & 0.98 & 0.88 & 1.00 & 0.43 & 0.96 & 0.80 \\
\hline BOC & 0.12 & 0.73 & 0.99 & 0.90 & 0.84 & 0.16 & 0.55 & 0.84 \\
\hline ECITIC & 0.91 & 0.73 & 0.97 & 0.86 & 0.47 & 0.42 & 0.62 & 0.83 \\
\hline PAB & 0.86 & 0.74 & 0.90 & 0.93 & 0.14 & 0.70 & 0.73 & 0.92 \\
\hline NBCB & 0.54 & 0.76 & 0.95 & 0.86 & 0.75 & 0.00 & 0.61 & 0.85 \\
\hline
\end{tabular}

TABLE IV. FINANCIAL RISK IMMUNE ABILITY EVALUATION RESULT OF LISTED BANKS IN 2015 (2)

\begin{tabular}{|c|c|c|c|c|}
\hline NAME & B1 & B2 & B3 & A \\
\hline SPDB & 0.83 & 0.78 & 0.79 & 0.93 \\
\hline HXB & 0.89 & 0.60 & 0.91 & 0.92 \\
\hline CMBC & 0.84 & 0.74 & 0.83 & 0.93 \\
\hline CMB & 0.91 & 0.87 & 0.90 & 0.96 \\
\hline NJCB & 0.45 & 0.55 & 0.82 & 0.81 \\
\hline CIB & 0.89 & 0.70 & 0.66 & 0.91 \\
\hline BOB & 0.61 & 0.51 & 0.72 & 0.83 \\
\hline ABC & 0.87 & 0.83 & 0.66 & 0.93 \\
\hline BOCOM & 0.78 & 0.87 & 0.44 & 0.88 \\
\hline ICBC & 0.62 & 0.91 & 0.67 & 0.89 \\
\hline CEB & 0.84 & 0.79 & 0.58 & 0.91 \\
\hline CCB & 0.74 & 0.95 & 0.73 & 0.92 \\
\hline BOC & 0.69 & 0.91 & 0.52 & 0.88 \\
\hline ECITIC & 0.87 & 0.77 & 0.62 & 0.91 \\
\hline PAB & 0.86 & 0.66 & 0.79 & 0.91 \\
\hline NBCB & 0.78 & 0.85 & 0.49 & 0.89 \\
\hline
\end{tabular}

It can be seen clearly from Table 3 and Table 4 that China Merchants Bank (CMB) gets the highest score of the immune ability financial risk of listed banks in 2015. The operating immunity ability of $\mathrm{CMB}$ is also the best in the industry. Huaxia bank (HXB) gets the highest score in immune ability of profit. Bank of China (BOC) gets the advantage in terms of repayment immunity ability. Table 5 is a comprehensive financial risk immune ability evaluation result of listed banks from 2010 to 2015:

TABLE V. FINANCIAL RISK IMMUNE ABILITY EVALUATION OF LISTED BANKS FROM 2010-2015

\begin{tabular}{|c|r|r|r|r|r|r|}
\hline NAME & 2015 & 2014 & 2013 & 2012 & 2011 & 2010 \\
\hline SPDB & 0.93 & 0.89 & 0.89 & 0.91 & 0.91 & 0.87 \\
\hline HXB & 0.92 & 0.93 & 0.91 & 0.91 & 0.93 & 0.92 \\
\hline CMBC & 0.93 & 0.90 & 0.89 & 0.89 & 0.91 & 0.86 \\
\hline CMB & 0.96 & 0.92 & 0.90 & 0.90 & 0.93 & 0.89 \\
\hline NJCB & 0.81 & 0.86 & 0.87 & 0.78 & 0.77 & 0.75 \\
\hline CIB & 0.91 & 0.91 & 0.90 & 0.82 & 0.90 & 0.84 \\
\hline BOB & 0.83 & 0.77 & 0.75 & 0.87 & 0.87 & 0.77 \\
\hline ABC & 0.93 & 0.92 & 0.92 & 0.92 & 0.82 & 0.86 \\
\hline BOCOM & 0.80 & 0.80 & 0.77 & 0.77 & 0.87 & 0.89 \\
\hline ICBC & 0.89 & 0.87 & 0.87 & 0.89 & 0.89 & 0.86 \\
\hline CEB & 0.91 & 0.88 & 0.87 & 0.92 & 0.87 & 0.87 \\
\hline CCB & 0.92 & 0.89 & 0.87 & 0.90 & 0.89 & 0.88 \\
\hline BOC & 0.88 & 0.82 & 0.85 & 0.90 & 0.89 & 0.87 \\
\hline ECITIC & 0.91 & 0.92 & 0.90 & 0.88 & 0.90 & 0.86 \\
\hline PAB & 0.91 & 0.90 & 0.87 & 0.93 & 0.92 & 0.88 \\
\hline NBCB & 0.89 & 0.84 & 0.89 & 0.87 & 0.89 & 0.89 \\
\hline
\end{tabular}

According to the evaluation results, the index score values at different layers and the overall evaluation results are not completely consistent. Some indicators show greater contrast, but the comprehensive score level are consistent with these banks' condition. The score of state-controlled commercial banks is between 0.79 and 0.92. Compared with other state-controlled commercial banks, the overall score of Bank of Communications (BOC) is the lowest; China Construction Bank (CBC) has the highest score. The score of joint stock commercial banks which is between 0.88 and 0.96 is much higher than that of state-controlled commercial banks. China Merchants Bank (CMB) has the highest score especially. From the point of time series, the vast majority (with the exception of Bank of Nanjing) of banks' financial 
risk of immune ability scores change from high to low from 2011 to 2013, which is in consistent with the change of China's economic environment. The score of Bank of China(BOC), Agricultural Bank of China(ABC) and Industrial and Commercial Bank of China(ICBC) in 2011 and 2012 increases slightly, but they also decease in 2012 and 2013, which means that the state-owned commercial banks can resist risks relying on its own strength in the short term when the risk come. However, risk management methods should be taken timely to deal with financial risk. The score of Bank of Nanjing remains almost stable, even rising a little bit, but it has a large degree of decline in 2015. It shows that Bank of Nanjing have the advantages in debtpaying immune ability, operating immune ability and earning immune ability, but it is difficult for it to process and memory threat factors which leads to an adverse effect on the long-term health development of the bank.

\section{REVELATIONS FOR THE CONSTRUCTION OF FINANCIAL RISK OF THE IMMUNE SYSTEM}

The root cause of the financial crisis is the improper treatment of the financial risk. Therefore, establishing a sound financial risk immune system is particularly necessary to prevent and control financial risks. China's banks should consciously apply the theory of organizational immunity into their financial risk management, and make efforts to the promotion of repayment immunity and operational immunity. In short, It is significant for China's Banks to establish and improve an efficient financial immune system and keep sustained and healthy development of enterprises on the basis of organizational immune theory.

\section{ACKNOWLEDGEMENT}

We thank Jinmian Han, Jiaqi Wang. The project was funded by a grant from Xi'an Academy of Social Sciences, the Xi'an philosophy and social science planning project 2016(16J100).

\section{REFERENCES}

[1] Ping Lv, "An empirical study of the immune mechanism of behavior affects the organization performance", Science and Technology Management, 2011.

[2] Hui Xu, ChunLi Ji, Ji Li, Bin Zhou, Xin Jin, "The study of small and mid-sized enterprise risk response is studied based on organizational perspective of immune mechanism", management of the world, 2011.

[3] Ping Lv, YiHua Wang, "Organization immune behavior and mechanism research", Chinese Journal of Management, 2011.

[4] Ping Lv, YiHua Wang, "Enterprise adaptability research based on immune perspective of organization", Scientific research management, 2008.

[5] R. Nicole, "Title of paper with only first word capitalized," J. Name Stand. Abbrev., in press.

[6] Beaver, Financial Ratios as Predictors of Failures in Empirical Research in Accounting Supplement to the Journal of Accounting Research (1968)M. Young, The Technical Writer's Handbook. Mill Valley, CA: University Science, 1989.

[7] ChunLan Dai, XiaoShu Ding, "Construction of enterprises internal control evaluation system based on immune theory", Finance and Accounting Monthly, 2013.

[8] Fan Li, ZhiTao Du, LingJuan Li, "Enterprise financial early warning model: theory review and comments", Management review, 2011.

[9] Lane W.R, S.W Looney, J.W Wansley, "An Application of the Cox Proportional Harzards model to Bank Failure". Journal of Banking and Financial, 1986.

[10] Altman ,E.I, Financial Ratios, CA: Discriminant Analysis and Prediction of Corporate Bankruptcy.1968. 